\author{
Rafat Godoń* \\ Warszawa
}

\title{
Uczenie się jako uczestnictwo w rozmowie ludzkości
}

Zmiany zachodzące $\mathrm{w}$ szkolnictwie $\mathrm{w}$ ostatnich latach powodują, że coraz częściej centralnym zagadnieniem poruszanym w refleksji na temat oświaty jest umiejscowienie i sens kształcenia ogólnego. Wątpliwości wzbudza między innymi to, w jakim stopniu praktyka edukacyjna wypełniona jest jeszcze myślą humanistyczną, w jakim zaś podporządkowana jest bieżącym potrzebom i oczekiwaniom rynkowym. Obawy o utratę tego, co stanowi raison d'être edukacji, wynikają ze zmiany roli, jaką w kształceniu odgrywa współcześnie humanistyka. Marginalizowaniu znaczenia kształcenia ogólnego w procesie dydaktycznym towarzyszy dziś zwiększanie wagi warsztatów praktycznych, które są w rzeczywistości formą szkoleń zawodowych. Nie jest to, jak wiemy, stan rzeczy dotychczas niespotykany. Relacja między kształceniem ogólnym a wiedzą specjalizacyjną już od dawna była żywo dyskutowana, a jej oczywistość nierzadko kwestionowana ${ }^{1}$. Jednak dziś dyskusje te mają, jak sądzę, wyjątkowe znaczenie. O ile bowiem jeszcze kilka dekad temu kondycja edukacji w kulturze Zachodu, choć bywała określana jako kryzysowa, to jednak nie wywoływała w jej głównych uczestnikach

* Dr hab. Rafał Godoń jest adiunktem w Zakładzie Pedagogiki Ogólnej i Filozofii Edukacji na Wydziale Pedagogicznym Uniwersytetu Warszawskiego.

${ }^{1}$ Por. H. Bergson, O specjalizacji, w: tenże, Wykłady o wychowaniu, thum. P. Kostyło, Warszawa 2004, s. 7-17. 
powszechnego poczucia gruntownego rozżalenia i zawodu, o tyle dziś sytuacja jest zasadniczo odmienna. Coraz częściej formułowana jest diagnoza o zmierzchu kształcenia lub nawet jego końcu i coraz poważniej brana jest ona pod rozwagę zarówno przez teoretyków, jak i przez uczestników kształcenia, w tym przez studentów ${ }^{2}$. Wydaje się, że jedną z przyczyn pesymistycznego przedstawiania stanu dzisiejszej oświaty jest niezgoda na sposób, w jaki kształcenie ogólne jest obecne we współczesnej edukacji. Czym zatem jest kształcenie ogólne i dlaczego zmiany w jego przebiegu niepokoją współczesnych?

Problematyczność kształcenia ogólnego można ukazywać na rożne sposoby. Jest to widoczne zwłaszcza w polskiej literaturze pedagogicznej, niezwykle żarliwie odsłaniającej humanistyczne niepokoje teoretyków wychowania ${ }^{3}$. Jednak tłem przedstawionych tu poszukiwań jest sposób, w jaki kilka dekad temu problematyczność kształcenia ogólnego zaistniała w dyskursie pedagogicznym prowadzonym w kulturze anglosaskiej, zwłaszcza za sprawą myśli filozoficznej Michaela Oakeshotta. Spośród prac tego autora na wyróżnienie zasługują eseje zebrane w tomie The Voice of Liberal Learning ${ }^{4}$, które zawierają główne tropy pedagogiczne podejmowane przez Oakeshotta. Rekonstrukcja głównego argumentu Oakeshotta w sprawie kształcenia ogólnego może być pomocna nie tylko w zrozumieniu tego, co wydarzyło się w anglosaskiej kulturze pedagogicznej ostatnich dekad, lecz również może przyczynić się do głębszego spojrzenia na problematyczność kształcenia ogólnego w naszych, polskich warunkach.

Inspiracją zaprezentowanych tu rozważań jest przede wszystkim esej A Place of Learning 5 , po raz pierwszy opublikowany w 1975 roku i później zawarty w przytoczonym już tomie prac pedagogicznych Oakeshotta. Czytając ten tekst i rekonstruując sens tego, czym jest uczenie się, postaram się znaleźć odpowiedź na pytanie dotyczące kształcenia ogólnego.

2 Por. J. Rutkowski, Zmierzch ksztatcenia? Wybrane implikacje pedagogiczne filozofii Leo Straussa i Erica Voegelina, Warszawa 2012.

${ }^{3}$ Por. L. Witkowski, Koniec kultury uczenia się? Edukacja $w$ dobie presji simulacrum konsumpcji (dyskusja nie tylko z Zygmuntem Baumanem), w: M. Jaworska-Witkowska (red.), Jaka kultura? Jaki dyskurs? Sfera publiczna a spory o edukację i zarządzanie, Szczecin 2008, s. 213-242.

${ }^{4}$ M. Oakeshott, The Voice of Liberal Learning, Indianapolis 2001.

5 Tenże, A Place of Learning, w: tenże, The Voice, s. 1-34. 


\section{Rozmowa ludzkości jako horyzont uczenia się}

Zacznę od zagadnienia, którego Oakeshott nie wyeksponował w tym eseju, lecz mimo to ma ono zasadnicze znaczenie w mojej lekturze tego tekstu. Chodzi o „rozmowę ludzkości”, sformułowanie, które na trwałe już weszło w język dyskursu pedagogicznego w kulturze anglosaskiej. Stało się to za sprawą eseju z 1959 roku Poezja i jej głos w rozmowie ludzkości $i^{6}$, w którym Oakeshott nie tylko daje wyraz temu, co uważa za istotne we współczesnej kulturze, lecz również stara się uchwycić swoistość relacji międzyludzkich charakteryzujących świat Zachodu. Nośność przekazu Oakeshotta bierze się być może z tego, że wyraża on istotę więzi społecznej za pomocą języka bliskiego codziennej komunikacji.

Mówiąc o rozmowie, Oakeshott ukazuje analogię między sposobem, w jaki na co dzień porozumiewamy się, a tym, jak współistnieją w kulturze różne zainteresowania i formy aktywności człowieka. Chodzi o to, że tak jak codzienna komunikacja ukierunkowana na współbycie wymaga od nas otwartości i rzeczywistej rezygnacji z dominacji, tak też kultura nie jest możliwa bez odrzucenia dążenia do wyłączności i panowania. Dlatego w A Place of Learning, określając znaczenie pojęcia „kultura”, Oakeshott mówi wprost o tym, że jest ona „konwersatoryjnym spotkaniem”, spotkaniem właśnie, a nie doktryną. Konwersacja nie polega, jego zdaniem, na wykazywaniu racji, przekonywaniu do własnej słuszności, udowadnianiu czy w ogóle dowodzeniu. Jest ona natomiast, jak pisze w eseju z 1975 roku, ,spontaniczną przygodą intelektualną" ${ }^{\mathrm{i}}$ dalej: „Właściwie nie jest ona możliwa bez różnorodności głosów: w niej spotykają się światy odmiennych dyskursów, by zyskać wzajemne uznanie i cieszyć się ową nieokreśloną relacją, która nie wymaga ani nie przewiduje ich wzajemnego dostosowania"9. To, co autor ceni wyjątkowo wysoko w rozmowie jako formie relacji międzyludzkich, to jej niekonkluzywność ${ }^{10} \mathrm{i}$ otwartość, które stanowczo nie pozwalają na wyłączenie kogokolwiek z udziału w jej doświadczeniu. Stąd cechą rozmowy jest

${ }^{6}$ Tenże, Poezja i jej głos w rozmowie ludzkości, w: tenże, Wieża Babel i inne eseje, tłum. Ł. Sommer, Warszawa 1999, s. 241-296.

7 Tenże, A Place, s. 16.

8 Tenże, Poezja, s. 244.

9 Tamże, s. 244-245.

10 Tenże, A Place, s. 30. 
przede wszystkim, jak można to ująć za pomocą sformułowania Michaiła Bachtina, wielogłosowość.

Jaki jednak sens ma mówienie o rozmowie ludzkości? Wydaje się, że tak metaforyczne wyrażenie dość daleko odbiega od bardzo konkretnego wymiaru, jaki ma rozmowa, jeśli rozważać ją jako formę codziennej komunikacji. Czy to metaforyczne sformułowanie wnosi jakiś nowy sens w przedstawianą przez Oakeshotta interpretację kultury? Ludzkość oczywiście nie prowadzi rozmowy w takim sensie, w jakim mogą to czynić konkretni ludzie. Jednak kultura rozumiana jako wytwór ludzkości może mieć cechy rozmowy, może właściwie być rozmową. Wytworem ludzkości w kulturze Zachodu jest to wszystko, co stanowi ślad relacji międzyludzkich, w tym między innymi dzieła sztuki, nauki czy filozofii. Nie należy jednak zapominać o działaniu i tym wszystkim, co stanowi jego urzeczywistnienie. Mówiąc inaczej, ludzkość wytworzyła różne formy budowania relacji miedzy ludźmi, na różne sposoby wyraża to, co istnieje w tych relacjach, używa zatem różnych języków i przemawia różnymi głosami, tworząc różnorodne wyobrażenia rzeczywistości. Dlatego w ujęciu Oakeshotta rozmowa ludzkości to „miejsce, w którym owe rozmaite języki wypowiedzi, składające się na współczesne stosunki ludzkie, spotykają się, by utworzyć jakąś złożoną całość”"11. W dalszej części tekstu zaś rozmową ludzkości nazywa „miejsce, w którym spotykają się różnego rodzaju sposoby tworzenia obrazów"12. W tych określeniach warto zwrócić uwagę na integracyjny charakter rozmowy ludzkości. To ona właśnie łączy, choć nie treściowo, a jedynie formalnie, wszystko to, co dzieje się między ludźmi. Dzięki otwartości rozmowy różne jej głosy spotykają się, bez obawy o to, że utracą swoją tożsamość. Spotkanie nie zagraża ich odmienności i niepowtarzalności. Do takich właśnie głosów Oakeshott zalicza naukę, działania praktyczne oraz poezję̨ ${ }^{13}$. Choć różne, a czasami zdaje się że nawet sprzeczne, nie wchodzą w żadną kolizję czy rywalizację, nie szkodzą współczesnej kulturze, a wręcz ją współtworzą. W tej sytuacji zadaniem uczestnika kultury jest znalezienie właściwego sposobu wsłuchiwania się w ich różnorodne wypowiedzi, a jego edukacja polega na wypracowaniu odpowiedniej reakcji na zaproszenia, które te głosy do niego skierowują.

\footnotetext{
11 Tenże, Poezja, s. 244.

12 Tamże, s. 252.

13 Tamże.
} 


\section{Swoistość uczenia się}

W eseju A Place of Learning, analizując znaczenie uczenia się, Oakeshott wskazuje na najważniejsze właściwości doświadczeń, które mają kształcący charakter i rzeczywiście są, jego zdaniem, formami uczenia się, a także na takie sytuacje, które są mylnie utożsamiane z kształceniem.

Zwrócenie uwagi w refleksji filozoficznej na uczenie się jako formę doświadczenia nie jest wynikiem logicznej kalkulacji czy nagłego, przypadkowego docenienia tej sfery życia, lecz naturalną sytuacją w czynności rozpoznawania tego, co wyznacza sens ludzkiego zamieszkiwania w świecie. Jak zauważa Oakeshott, uczenie się jest nierozerwalnie związane z byciem człowiekiem i dlatego stanowi centralny problem ludzkiego samorozumienia: „Ta nierozdzielność uczenia się i bycia człowiekiem jest kluczowa dla naszego rozumienia siebie. Oznacza to, że nikt nie rodzi się człowiekiem; każdy jest tym, czego się nauczy"14. Wszystko, co człowiek myśli, co mówi i przeżywa, jest tym, czego się nauczył. „Nawet ludzka śmierć jest czymś, czego [człowiek] się nauczył"15. Tak silny związek uczenia się ze sposobem, w jaki osoba jest $\mathrm{w}$ świecie, powoduje, że nie można przecenić znaczenia edukacji dla rozumienia ludzkiej kondycji. Uczenie się nie tyle poszerza wolność człowieka, ile samo jest emancypacją, samo jest doświadczeniem wolności. Za sprawą uczenia się ,,człowiek jest $w$ sobie tym, kim jest dla siebie" ${ }^{16}$. Stawanie się człowiekiem to proces nieustannie ponawianego dystansowania się do tego, co tu i teraz, do tymczasowości i do siebie samego.

$\mathrm{Z}$ punktu widzenia Oakeshotta uczenie się konstytuuje ludzką egzystencję. Dlatego właśnie „każdy człowiek jest swoją własną samoaktualizującą się «historią», a wyrażenie «natura ludzka» oznacza wyłącznie nasze wspólne i nieuniknione zaangażowanie: "stawać się przez uczenie się» ${ }^{17}$. Chodzi więc o to, że konsekwencją rozumności człowieka jest to, że jego zasadniczym określeniem jest uczenie się, które nieustannie włącza człowieka w tradycję i jej dzianie się i przez to nadaje jego życiu ponadjednostkowy i ponadpartykularny wymiar. Jednocześnie jednak Oakeshott wydobywa w analizie ludzkiego doświadczenia istotę myślenia o człowieczeństwie w kategoriach uniwersalnych: jedynym sensownym uzasadnieniem takiej

\footnotetext{
14 Tenże, A Place, s. 6.

15 Tamże, s. 10.

16 Tamże, s. 4.

17 Tamże, s. 6
} 
uniwersalnej perspektywy jest uchwycenie i wyartykułowanie tego, co łączy istoty ludzkie, a tym jest właśnie uczenie się, które jest jednocześnie sposobem kształtowania się naszego człowieczeństwa. Autor wprost zauważa, że inne, treściowe określenia „natury człowieka” są zawsze wynikiem nadużycia i kończą się przywoływaniem sformułowań, które nie mają żadnego sensownego odniesienia do rzeczywistości.

Warto zauważyć także, że spełnienie tak poważnych oczekiwań wobec uczenia się nie jest sprawą łatwą ani pewną. Uczenie się nie jest tu bowiem rozumiane jako proces dydaktyczny, który można zaplanować, przygotować i przeprowadzić. Wymaga ono od osoby czegoś znacznie bardziej skomplikowanego niż to, co jako technika kształcenia występuje w metodyce postępowania dydaktycznego. Uczący się nie tylko ma rozumieć złożoność tego, czym jest uczenie się, lecz również ma sam zaangażować się w proces uczenia się. Oznacza to, że prawdziwe kształcenie nie jest możliwe bez personalnego włączenia się ucznia $\mathrm{w}$ doświadczaną materię, która ma sens. Właśnie ukierunkowanie na znaczenie tego, co ewokuje uczenie się, jest często niedocenianą cechą tego procesu. A przecież bez „refleksyjnego zaangażowania" ${ }^{18}$ człowiek nigdy nie może być uczniem. Uwaga ta dotyczy, rzecz jasna, każdego, kto się uczy. Dlatego w odniesieniu do tradycyjnych ról społecznych skierowana jest ona także do nauczycieli, a nie tylko do uczniów, oni także nauczając, uczą się. Skupienie w kształceniu na konkretnej rzeczy powoduje, że uczenie się może stać się udziałem każdego, bez względu na wiek i rolę społeczną, która została mu zwyczajowo i sytuacyjnie przypisana.

Niestety, uczenie się wciąż nazbyt często bywa utożsamiane z abstrakcyjnymi kompetencjami, które nie mają nic wspólnego z rzeczywistą, konkretną sytuacją człowieka. Opisując składniki kształcenia ogólnego (komponenty edukacji liberalnej), Oakeshott stara się wykazać, że ogólność kształcenia wcale nie oznacza oderwania od konkretnej rzeczywistości, a konceptualizacje sugerujące ideę „pedagogiki ogólnej” [general education] prowadzą do nieporozumienia w sprawie sensu kształcenia ogólnego [liberal learning] ${ }^{19}$. Choć w takim ogólnym ujęciu pedagogika stroni od bezpośrednich okoliczności [the here and now] sytuacji uczenia się, to jednak jest jednocześnie pozbawiona jakiegokolwiek sensownego ukierunkowania na to, co godne wysiłku uczenia się. Można powiedzieć, że pedagogika ogólna jest hipostazą, jeśli miałaby oznaczać koncentrację na ogólnej dyspozycji pedagogicznej. Uczenie się nie polega na „rozwoju”, „doskonaleniu umysłu” czy „nauce

\footnotetext{
18 Tamże, s. 7.

19 Patrz: tamże, s. 20-21.
} 
myślenia", ponieważ uczyć się można tylko czegoś, co zostało określone, w przeciwnym wypadku mamy do czynienia z sytuacją pozbawioną sensu, niczym orkiestra, która gra muzykę w ogóle, a nie konkretny utwór, zauważa Oakeshott ${ }^{20}$. Zgodnie ze stereotypowym przekonaniem w sprawie kształcenia ogólnego, jego głównym zadaniem jest tworzenie „miękkich” kompetencji ucznia, takich między innymi jak ,uczenie się myślenia dla samego siebie”, „rozwijanie inteligencji”, „myślenie logiczne” lub „deliberatywne”, dokładność, a także przejrzystość czy klarowność wypowiedzi. Dziś rozszerzając nieco interpretację Oakeshotta, można uznać, że najmodniejszym atrybutem takiej edukacji jest myślenie krytyczne. Należy przy tym zauważyć, że sam Oakeshott wymienia wśród tych domniemanych wyzwań edukacji także zdolność do rozpoznawania błędów w rozumowaniu i nieuleganie logicznym pułapkom intelektualnym. Rzecz jednak w tym, jak twierdzi Oakeshott, że te wszystkie zdolności i umiejętności nie mogą zostać uznane za przedmiot kształcenia, ponieważ te „ogólne” dyspozycje nie decydują o sednie i jakości kultury. Edukacja pozbawiona merytorycznego ukierunkowania na rzecz udaje jedynie rzeczywiste kształcenie, które zawsze jest przecież związane z konkretnym obszarem lub dziełem kulturowym. Kultura nie jest zbiorem zdolności czy umiejętności, lecz wyrażaniem między innymi myśli, uczuć, przekonań czy opinii, a edukacja we właściwym znaczeniu tego słowa wspiera uczniów w rozumieniu tych konkretnych doświadczeńn ${ }^{21}$. Dlatego właściwie pojmowane uczenie się nie jest „ogólnym” kształtowaniem „miękkich” kompetencji, lecz zawsze doświadczeniem konkretnego wytworu kulturowego.

Uczenie się bywa także mylone $\mathrm{z}$ takimi formami ludzkiego doświadczenia, których struktura już od początku uniemożliwia zaistnienie sytuacji refleksyjnego myślenia, kształtującego człowieka. Chodzi o dość często dziś obecne w instytucjach edukacyjnych różnego rodzaju szkolenia i warsztaty, mające na celu przygotowanie uczestników do wykonywania czynności zawodowych. Czasami zawodowość nie oznacza pełnych kwalifikacji do wykonywania prac w danej profesji, a jedynie ich element. Jednak tym, co w decydujący sposób nie pozwala na zaliczenie tego typu doświadczeń do obszaru uczenia się, jest ich ukierunkowanie nie na kształtowanie się człowieczeństwa uczestnika takich szkoleń, lecz na jego sukces w wykonywaniu czynności społecznie użytecznych. Dlatego treningi i kursy szkoleniowe, choć być może przydatne dla funkcjonowania jednostki w społeczeństwie,

\footnotetext{
${ }^{20}$ Por. tamże, s. 10.

${ }^{21}$ Por. tamże, s. 21.
} 
nie mają charakteru kształcącego w tym sensie, w jakim uczenie się jest modi wolności. Mówiąc wprost, celem takich pseudoedukacyjnych przedsięwzięć nie jest dobro człowieka i troska o kondycję ludzką, lecz przygotowanie siły roboczej dla kapitału. Oczywiście, że wyrabianie różnego rodzaju nawyków i kształtowanie umiejętności wchodzą w zakres kształcenia par excellence, ale tylko wówczas, gdy są ściśle podporządkowane idei kształcenia ogólnego, to jest podnoszenia człowieczeństwa. Stosowanie różnego rodzaju sztuczek dydaktycznych i uatrakcyjnianie szkoleń za pomocą nowoczesnych technologii nie zmienia ich ograniczonego charakteru i nie unieważnia negatywnej oceny, jaką one uzyskują w kontekście wymagań, stawianych w naszej kulturze wobec osoby wykształconej.

Jeszcze innym mankamentem współczesnych prób wdrażania uczenia się jako formy doświadczenia pedagogicznego jest konceptualizowanie uczenia się jako samorealizacji. W myśl takiego wyobrażenia uczenie się jest teleologicznym procesem, w którym człowiek odsłania swój potencjał ${ }^{22}$. Oznacza to, że to, co stanowi sedno ludzkiego bycia w świecie, jest już w człowieku, w jego wnętrzu obecne; jako swego rodzaju depozyt czeka, aż ktoś odkryje jego istnienie. Oakeshott przeciwstawia się takiemu wyobrażeniu uczenia się: „Uczenie się nie jest także teleologicznym procesem, w którym hipotetyczne [suppostious] ziarno humanitas wyrasta i realizuje się w każdym z nas" ${ }^{23}$. Taka magiczna wizja uczenia się jest zdaniem Oakeshotta nieporozumieniem. „Bycie zaczarowanym nie jest uczeniem się”24 - mówi autor, dając w ten sposób wyraz swojej dezaprobacie dla wszelkich pozbawionych racjonalności starań wyjaśnienia uczenia się.

\section{Miejsca uczenia się}

Wbrew panującym stereotypom uczenie się nie jest przypisane do jednego okresu w życiu, a podejmowanie kształcenia po uzyskaniu dojrzałości nie powinno dziś nikogo dziwić. Przeciwnie, można powiedzieć, że zaskakujące powinno być dla nas lekceważenie uczenia się w okresie dorosłości, ponieważ to właśnie dorośli powinni doskonale rozumieć, czym jest uczenie się. A jest ono przecież „całożyciowym zaangażowaniem” [lifelong engagement], które urzeczywistnia się w świecie. Mimo iż to świat jako ca-

\footnotetext{
22 Tamże, s. 8.

23 Tamże.

${ }^{24}$ Tamże.
} 
łość jest właściwym miejscem uczenia się, jak zauważa Oakeshott, człowiek poznając rzeczywistość, zawęża obszary, w których uczenie się jest szczególnie wyeksponowane. Tak wyróżnionymi miejscami są rodzina, szkoła i uniwersytet ${ }^{25}$.

W swoich rozważaniach Oakeshott skupia się na instytucjach oświatowych tradycyjnie kojarzonych z nauczaniem, to jest na szkole, a także na uniwersytecie. Nie oznacza to jednak, że nie docenia znaczenia rodziny w uczeniu się:

Ludzka rodzina (w każdej formie) jest praktyką wymyśloną nie dla prokreacji dzieci ani po prostu dla opieki nad nimi, lecz dla wczesnej edukacji nowoprzybyłych [newcomers] na ludzką scenę: to uprzytamnia, że uczenie się zaczyna się powoli i wymaga czasu. Szkoła i uniwersytet są niezwykle charakterystyczne; są kolejnymi etapami rozważnego wchodzenia [engagement] w uczenie się ${ }^{26}$.

Zasadnicza wątpliwość, jaka nasuwa się w kontekście tego fragmentu, dotyczy znaczenia „wczesnej edukacji nowoprzybyłych”. Kiedy ta forma kształcenia jest właściwym miejscem uczenia się? Jaka praktyka edukacyjna dotycząca dzieci może być utożsamiana z tym, czym uczenie się jest w swej istocie?

Wątpliwości dotyczące rodziny jako miejsca kształcenia rozwiewa przemyślenie sensu pozostałych takich miejsc. Szkoła i uniwersytet to nie tyle instytucje, których działalność jest kwestią głównie organizacji i zarządzania, ile przestrzenie, w których człowiek doświadcza tego, co stanowi istotę jego bycia w świecie. „Szkoła i uniwersytet to oddzielne miejsca, w których ten, kto chce się uczyć, uwalnia się od ograniczeń swojej sytuacyjności, a także od pragnień, które dotychczas uznawał za oczywiste i zostaje poruszony przez to, co daje do myślenia, a czego dotychczas nie dostrzegał"27. Osoba naprawdę ucząca się uczestniczy w rozmowie ludzkości w tym sensie, że nabierając dystansu do własnych ograniczeń związanych z pragnieniami, jednocześnie wyrabia w sobie umiejętność słuchania i prowadzenia konwersacji. Dlatego największa trudność w uczeniu się dotyczy rozpoznania tego, co godne uwagi, i niepomijania zaproszeń, które tradycja skierowuje do każdego, kto się uczy.

\footnotetext{
25 Tamże, s. 10.

26 Tamże.

27 Tamże, s. 11.
} 
W takim świetle sprawa rodziny jako miejsca kształcenia nabiera szczególnego wymiaru. Pedagogicznym zadaniem rodziny jest przede wszystkim wspieranie dziecka we włączaniu się w kulturę i to nie za pomocą indoktrynującego przekonywania o wyższości spraw kulturowych nad rodzinnymi czy prywatnymi, lecz przez kształtowanie atmosfery uważnego i niepośpiesznego, wzajemnego wsłuchiwania się w to, co członkowie rodziny mają do przekazania. Oczywiście trudność polega tu nie tylko na tym, jak taką aurę stworzyć, ale również na właściwym doborze tego, co można mieć do przekazania w relacji z dzieckiem. Zapewne nie każdy temat rozmowy będzie właściwy dla konkretnego dziecka, ale nigdy też nie można z góry przesądzić, że jakiegoś zagadnienia na pewno należy unikać. Chodzi o to, aby dziecko nie czując zbędnej presji dostrzegało jednak wartość uczestnictwa w rozmowie, jaka toczy się w kulturze Zachodu. Rodzina powinna zatem zabiegać o to, aby te wczesne doświadczenia pedagogiczne nie wytworzyły w dziecku przekonania, że dzieła kulturowe są ,przedmiotami” do nauczenia się i biernego ,podziwu”, a świat wymaga od nas jedynie przyswojenia dobrze już rozpoznanych prawd. Istotne jest więc, aby dziecko $\mathrm{z}$ otwartością reagowało na zaproszenia najwybitniejszych wytworów kultury i miało czas, aby takie zaproszenia rozważyć i z nich skorzystać. Wydaje się, że spontaniczność i żywiołowość dzieci nieomal gwarantują, że ten wczesny etap edukacji nie będzie czasem straconym z punktu widzenia tego, czym jest uczenie się. Można mieć jednak poważne obawy, czy optymizm w tej sprawie jest postawą zasadną. Dlaczego bowiem osoby wkraczające w dorosłość tak często nie widzą już sensowności podejmowania tego, czym jest uczenie się, zwłaszcza w wymiarze kształcenia ogólnego?

Warto w tym miejscu zauważyć, że postawa osoby uczącej się nie pojawia się w życiu człowieka nagle, nie wiadomo skąd i niezależnie od wszelkich okoliczności. Duże trudności ze zrozumieniem tego, czym jest uczenie się, może mieć osoba, która w dzieciństwie była poddawana rozlicznym zabiegom doskonalącym, które jednocześnie ograniczały, a następnie eliminowały jej zainteresowanie. Dziecko, jak wiadomo, jest odkrywcą i najczęściej z dużym zapałem stara się rozpoznać otaczający je świat. Jak długo jednak może ono utrzymać postawę zainteresowania w sytuacji wypierania jej przez ambicje dorosłych?

Negatywny wpływ otoczenia na kształtowanie się postawy uczącego się dziecka bardzo wyraźnie ukazuje sytuacja uczniów, którym rodzice organizują liczne zajęcia dodatkowe, mające zapewnić im wszechstronne wykształcenie. Przekonanie rodziców o tym, że dziecko powinno szybko i skutecznie opanowywać wiedzę, a postępy w nauce można mierzyć w skali ukazywanej 
w rankingach osiągnięć, najlepiej odsłania kulisy rodzinnego życia pedagogicznego. Niestety to nastawienie na zdobywanie wiedzy i sukces nie jest dziś sprawą marginalną, a ideologia sukcesu jest często wzmacniana przez szkołę i jej urzędników.

Jednak szkoła wcale nie musi być miejscem przygotowywania do wyścigu, może być miejscem uczenia się. W takim przypadku musi ona uczyć dzieci dystansu do oczekiwań zarówno własnych, jak i otoczenia, a także wyrabiać w uczniach przekonanie o wysokim znaczeniu wykształcenia jako formy rozumienia świata. Uczeń, który wbrew własnym pokusom, nierzadko także roszczeniom najbliższych, czyta książki po to, aby rozumieć to, co dzieje się w jego życiu i otoczeniu, a nie dla zaspokojenia apetytu ${ }^{28}$ tego otoczenia, wkracza w rzeczywistą przestrzeń uczenia się. Właśnie taki uczeń jest dobrym kandydatem na studenta. Posiadł wiedzę, która nie jest zbiorem nieistotnych dla niego informacji, lecz wyobrażeniem świata, w którym wzrasta. Co więcej, to taki właśnie uczeń rozumie, w jaki sposób kultura zaprasza go do uczestnictwa w uczeniu się, rozpoznaje to zaproszenie i twórczo je przyjmuje ${ }^{29}$.

Najbardziej charakterystycznym miejscem uczenia się jest uniwersytet. To tu dopiero rzeczywiście widać, że uczenie się jest wyrazem wolności. $\mathrm{W}$ przeciwieństwie do ucznia, który właściwie nie ma wyboru, to jest nie może nie być uczniem, student sam decyduje o swojej nauce. Nikt nie zmusza go do uczenia się i być może dlatego ma ono dla niego już od początku inne znaczenie niż dla ucznia. Co więcej, w uniwersytecie uczący się doświadcza przygodności uczenia się. Oznacza to, że pytania, które stawiają wielkie dzieła kultury Zachodu, mogą przemówić do uczącego się, ale tylko wtedy, kiedy wydarzy się coś, co tę rozmowę otworzy. Doświadczenie takiej rozmowy jest przygodą, a uczący się uczestniczy w niej nie dlatego, że ktokolwiek od niego tego oczekuje, lecz z tego powodu, że przyjął zaproszenie, które usłyszał, obcując z tradycją.

\section{Podsumowanie}

Z perspektywy Oakeshotta wartość edukacji nie jest zależna od jej przydatności i tego, w jakim stopniu spełnia wymagania zmieniającego się ryn$\mathrm{ku}$. Kształcenie na każdym poziomie oznacza przede wszystkim wspieranie

\footnotetext{
28 Por. tamże, s. 33.

${ }^{29}$ Por. tamże, s. 31.
} 
tego, co w ludzkim doświadczeniu świata jest najcenniejsze i najbardziej wyjątkowe, a tym właśnie są chwile, w których człowiek poszerza granice swojego rozumienia. „Kształcenie ogólne [liberal learning] jest uczeniem się odpowiadania na zaproszenia wielkich intelektualnych przygód, w których człowiek daje wyraz różnorodnym formom rozumienia świata i samego siebie" ${ }^{30}$. Idea kształcenia ogólnego nie polega jednak jedynie na intelektualnym przemyśliwaniu i zdobywaniu wiedzy. Kształcenie ogólne to przede wszystkim uczenie się, które zmienia uczącego się i jego świat. Taka zmiana nie jest bezpiecznym czy neutralnym przetwarzaniem informacji, lecz wydarzeniem, które przewraca świat do góry nogami. Być może dziś, kiedy zegary odmierzają czas coraz szybciej, a możliwości innowacyjnego wygenerowania ludzkich pragnień są coraz większe, kształcenie, w którym liczy się nie to, jak wiele zdobędziemy, lecz to, co dzieje się z osobą uczącą się i z jej rozumieniem świata, nie ma już wielkiego znaczenia. Być może jednak nadszedł czas, w którym ta „wywrotowa” właściwość kształcenia ogólnego znów ukaże swoje walory. Być może jeszcze raz skieruje pokolenie „nowoprzybyłych na ludzką scenę” ku dziełom kulturowym i przeszłości po to, by doświadczając wciąż żywej tradycji, mogło ono zrozumieć, w jak skomplikowanym i bogatym świecie przyszło nam żyć.

\section{Learning as an Engagement in the Conversation of Humankind (Summary)}

The paper discusses the idea of liberal learning presented by Michael Oakeshott in his essay "A Place of Learning". The central argument of this interpretation is that Oakeshott's concept of liberal education may be helpful for understanding the current situation in Polish educational institutions. After introducing the meaning of "the conversation of the humankind", the author analyses two crucial issues for his interpretation of this essay: the key features of the experience of learning and the metaphor of a place of learning. Pinpointing three main areas of learning, that are, according to Oakeshott, family, school and university, he interprets their significance as forms of liberal education.

Keywords: conversation; culture; learning; liberal education; Michael Oakeshott; school; self-understanding; tradition, university.

30 Tamże, s. 22. 


\section{Uczenie się jako uczestnictwo w rozmowie ludzkości (Streszczenie)}

Artykuł jest próbą podjęcia dyskusji wokół koncepcji uczenia się przedstawionej przez Michaela Oakeshotta w eseju Miejsce uczenia się. Główna teza w interpretacji tego eseju dotyczy możliwości pogłębienia rozumienia polskiej praktyki edukacyjnej przez odniesienie do tego, co Oakeshott określa jako kształcenie ogólne. Po wprowadzeniu znaczenia pojęcia „rozmowy ludzkości”, autor prezentuje analizę dwóch zagadnień istotnych dla jego interpretacji tego eseju: swoistości doświadczenia uczenia się oraz metaforyczności miejsca uczenia się. Wyróżniając za Oakeshottem trzy główne obszary uczenia się, a mianowicie rodzinę, szkołę i uniwersytet, autor ukazuje ich znaczenie jako form kształcenia ogólnego.

Slowa kluczowe: kształcenie ogólne; kultura; Michael Oakeshott; rozmowa; samorozumienie; szkoła; tradycja; uczenie się; uniwersytet. 
